Вісник Національного університету “Львівська політехніка”. Комп’ютерні науки та інформаційні технології. - 2011. - № 694. - С. 353.

4. Нечай О. Розроблення моделей загроз для друкованих документів, захищених графічними методами захисту / О. Нечай, М. Назаркевич., Ю. Христиніна // Вісник Національного університету «Львівська політехніка». - 2013. - С. 171.

5. Назаркевич М., Троян О. Аналіз сучасних методів та видів графічного захисту друкованих документів / Марія Назаркевич, Оксана Троян // Вісник Національного університету «Львівська політехніка». 2014. - c. 61, 64.

6. Maria Nazarkevych Analysis of Software Protection and Development of Methods of Latency in Printed Documents /Maria Nazarkevych, Oksana Troyan// In Proc. of the VIII ${ }^{\text {th }}$ International Scientific and Technical Conference CSIT 2013, 16-18 November, Lviv 2013, p. 120-121.

7. Дронюк I.M. Моделювання загроз та графічний захист для матеріальних носіїв інформації / I.М. Дронюк // Вісник Національного університету «Львівська політехніка». - 2013. - 78 с.

DOI https://doi.org/10.30525/978-9934-588-92-1-87

\title{
ТЕХНІКО-КРИМІНАЛІСТИЧНЕ ДОСЛІДЖЕННЯ ВОДЯНОГО ЗНАКУ ЯК ЕЛЕМЕНТУ ЗАХИСТУ ДОКУМЕНТІВ
}

\author{
Дідус Д. О. \\ студент \\ Інституту права \\ Київського національного університету імені Тараса Шевченка \\ м. Київ, Украӥна
}

Будь-яка держава не може повноцінно функціонувати без власної національної валюти. Держава зацікавлена у тому, щоб валюта виготовлялась централізовано, під iї контролем i не підлягала підробленню. Тому грошові знаки виготовляються зі спеціальними засобами захисту від фальшування [1, с. 204].

Спеціальні засоби захисту від підроблення - це сукупність технічних прийомів i засобів, які використовуються у процесі виробництва виробів суворого обліку, 3 метою захисту їх від несанкціонованого виготовлення (повного підроблення) та істотного 
ускладнення внесення до них будь-яких змін (часткового підроблення). Засобами захисту від підроблення можуть бути спеціальні матеріали, технології та елементи захисту (здатність паперу або фарби флюоресціювати в УФ променях; наявність водяних знаків, захисних стрічок, волокон; використання комбінованого способу друкування зображень; захисні сітки, гільйоширні візерунки, голографічні зображення, захисна плівка, мікротексти, мікроштрихові зображення тощо) [1, с. 205].

Водяний знак - видиме зображення або малюнок на папері, який виглядає світліше при перегляді на просвіт (або темніше при перегляді у відбитому світлі на темному фоні). Водяний знак одержують вдавленням металевого сітчастого валика або егутера (дендіролі, рівнителя) в папір в процесі його виготовлення. Малюнок водяного знака - лінії різної форми, букви або монограми, фігурні зображення.

Вперше водяні знаки з'явилися в Болоньї (Італія) в 1282 або 1283 році. Виробники паперу застосовували їх тоді i пізніше для ідентифікації своєї продукції, а також на поштових марках , банкнотах і інших державних документах для захисту від підробки [4, с. 2288].

Водяні знаки можна розділити на види: темний - елементи водяного знака темніші за тло паперу; світлий - елементи водяного знака світліші за тло паперу; двотоновий - синтезує перших два види; багатотоновий - синтезує елементи двох перших із поступовими переходами між ними. ) [1, с. 208].

За способом фіксації водяні знаки розділяють на:

- a) фіксовані - зі строго фіксованим місцем розташування;

- б) нефіксовані (“плаваючі”) - вони не мають чіткого місця розташування.

За змістом водяні знаки на банкнотах можна розділити на три види:

- а) надписи та малюнки;

- б) візерунки, фігури або цифри;

- в) портрети.

За розташуванням водяні знаки поділяються на такі види:

- $\quad$ 1)локальний водяний знак може розміщуватися на вільному від друку полі банкноти (купоні) (наприклад, українські гривні зразка 1994 та 1995 років тощо) або на купоні, якщо все поле банкноти задруковане (наприклад, англійські фунти стерлінгів). Такий знак виготовляється 3 допомогою круглосіткової папероробної машини;

- 2) загальний водяний знак являє собою рівномірне повторювання того самого зображення, але по всій площі банкноти. Такий знак виготовляється переважно 3 допомогою плоскосіткової 
папероробної машини (валдендироль встановлюється на сітку столової папероробної машини та при своєму обертанні утворює на вологому паперовому полотні відбиток свого рельєфу);

- 3) смуговий водяний знак характеризується його повторенням не по всій площі банкноти, а у визначеній ії частині [1, с. 209].

Паперові купюри мають кілька рівнів захисту. Серед них обов'язково присутній такий захист, як водяні знаки, які також є й своєрідною прикрасою. Створюються водяні знаки ще під час процесу відливу паперу. Створити чіткий i якісний водяний знак досить складно, тому для даних цілей використовується лише найсучасніше обладнання.

Центральні банки всіх основних світових валют вбудовувують водяні знаки в банкноти для захисту від підробки валют. Об'єднання різних ефектів водяних знаків в одному дизайні створює унікальний i привабливий образ для підвищення безпеки та полегшення автентифікації. Постійний розвиток нових технологій на водяних знаках дозволяс реалізувати нові графічні ефекти, які краще реалізують дизайни художника у папері з банкнотами.

Щодо виготовлення водяного знаку, то технологічно вони формуються за рахунок локальних розходжень в оптичній щільності паперу. У процесі виготовлення паперу початкова сира маса в папероформуючій машині розподіляється по поверхні металевої відливної сітки і притискається до останньої сітковим вирівнюючим валом, на якому розміщуються рельєфні зображення або написи. У місцях, що відповідають випуклим формам візерунка, розміщується менша кількість волокон паперової маси, а тому шар паперу виходить тоншим, i навпаки. Відповідно ці ділянки паперу мають i різну щільність, тому на просвіт більш прозорими $є$ ділянки 3 меншою щільністю паперу, а менш прозорі - 3 більшою щільністю паперу. Таким чином, при вивченні документа на просвіт повинні бути чітко видимі певні зображення або написи. [2, с. 171].

Далі потрібно розглянути, яким чином імітують водяні знаки і яким чином експерт може виявити таку імітацію.

Водяні знаки найчастіше імітують наступними способами:

1. Наносять на папір фарбою відповідний малюнок. При цьому ділянки, покриті шаром фарби (наприклад, білої, що у відбитому світлі зливаються 3 поверхнею білого паперу i погано помітні), при розгляданні на просвіт виявляються більш темними. Малюнок, який імітує водяний знак, наносять або з внутрішньої сторони паперу (якщо банкнота склеєна $з$ двох аркушів) або на звороті. Існують два основних 
способи виконання такої імітації: ручним способом, з використанням спеціально кустарно виготовленого кліше або друкуванням за допомогою офсетних друкарських форм, кліше, офісної техніки або трафаретів.

2. Так звані жирові водяні знаки (переважно для імітації світлих знаків), які наносять жировою речовиною (наприклад, рослинною олією або тваринним жиром) з використанням спеціально виготовлених 3 резини, деревини або металу кліше чи трафаретним способом. При цьому оброблені ділянки стають більш прозорими, ніж усі інші. Така імітація легко виявляється за допомогою тампона, змоченого у спирті (жир розчиниться і знаки стануть невидимими).

3. Кислотні водяні знаки виготовляються за допомогою місцевого впливу хімічного реагенту (це можуть бути засоби побутової хімії, розчини соляної та сірчаної кислоти тощо) на папір для зміни його оптичної щільності. Для нанесення цієї імітації використовують загострені предмети або спеціально виготовлені кліше.

4. Водяні знаки з припуском - така імітація зустрічається досить рідко. Вона складається з виготовлення спеціальної паперової суміші у вигляді густої пасти, яка наноситься на папір підробленої банкноти загостреним предметом або спеціально виготовленим кліше для глибокого друку та фіксації отриманого зображення за допомогою преса. Така імітація виявляється у процесі уважного дослідження у косо спрямованих променях.

5. Вирівняні водяні знаки, які наносять таким способом: підчищають гострим лезом або наждачним папером верхній шар паперу, після чого він у відповідних місцях стає тоншим i, отже, прозорішим (цей спосіб рідко зустрічається та ефективний лише для імітації світлих водяних знаків). Така імітація легко виявляється у процесі уважного дослідження водяного знака у косо спрямованих променях.

6. Рельєфні водяні знаки - наносять із використанням рельєфного металевого кліше без використання барвників, із відповідним зображенням. Потім притискають його до зволоженого паперу (при зволоженні волокна паперу розбухають, а під тиском руйнуються й сплющуються). У результаті на просвіт зображення стають видимими.

Також можливе нанесення такої імітації на готовий підроблений грошовий знак без зволоження. Обидва різновиди вказаної імітації легко виявляються при зволоженні ділянки банкноти зі знаком (можливе використання $10 \%$-го лужного розчину): справжній водяний знак при цьому стане ще більш яскраво видимим, а імітація зникне [3, с. 245]. 


\title{
Література:
}

1. Техніко-криміналістичне дослідження документів : навч. посіб. / [авт. кол. : О. В. Воробей, А. В. Кофанов]. - К. : Нац. акад. внутр. справ, 2011. - С. 204-209.

2. Біленчук П.Д. Криміналістика: Підручник. / П.Д. Біленчук, В.К. Лисиченко, Н.І. Клименко // Атіка. - К. - 2001. - С. 171.

3. Воробей О.В. Методика судово-технічної експертизи документів (загальна частина) / О.В. Воробей // Затверджено на засіданні КМР ДНДЕКЦ МВС України Протокол № 15 від 27.04. 2006. - К. - 2006. С. 245.

4. Encyclopedia of Library and Information Science / Ed. by M. J. Bates, M. N. Maack and M. A. Drake. - 2nd edn. - Marcel Dekker, 2003. - C. 22-88.

DOI https://doi.org/10.30525/978-9934-588-92-1-88

\section{FORENSIC RECOMMENDATIONS FOR THE PRE-TRIAL INVESTIGATION AS A MEANS OF ENSURING THE ACCESS TO A FAIR TRIAL IN CRIMINAL PROCEEDINGS}

\author{
Kovalenko A. V. \\ PhD in Law, \\ Associate Professor at the Chair of Criminal-Law Disciplines \\ Luhansk State University of Internal Affairs named after E. O. Didorenko \\ Sievierodonetsk, Luhansk region, Ukraine
}

Bringing a person to criminal justice is an excessive and very responsible activity. Any mistake by the authorities can lead to the punishment of innocent people, criminals will avoid responsibility and continue to harm society. As a result, criminal procedure is very carefully regulated, and the requirements and standards for criminal prosecution are clearly established by both national and international law.

The current Criminal Procedure Code of Ukraine includes the tasks of criminal proceeding to ensure prompt, complete and impartial investigation and trial so that everyone who has committed a criminal offense is prosecuted to the extent of his guilt, no innocent person has been accused or convicted, no person has been subjected to unreasonable procedural coercion and that proper legal procedure has been applied to each participant in the 